\title{
СОЦИОЛОГИЯ
}

DOI: $\underline{10.17805 / g g z .2019 .1 .5}$

\section{Чикагская социологическая школа: начало качественной стратегии в эмпирической социологии}

\author{
В. А. Луков
}

Московский гуманитарный университет, Д. А. Тихомиров

Российский экономический университет им. Г. В. Плеханова

В статье показаны основные черты Чикагской соџиологической школь, сложившейся вокруг Р. Парка и Э. Бёрджесса в 1920-1930-е г2. Вылвлена роль этой школь в становлении качественной стратегии в соииологии. Представлены особенности Чикагской школы и других научных школ в ключе тезаурусного подхода.

Ключевые слова: соииология; Чикагская сочиологическая школа; качественная стратегия; эмпирической сочиологии; Роберт Парк; Эрнст Бёрджесс; тезаурусный подход

\section{The Chicago School of Sociology: The Rise of the Qualitative Strategy in Empirical Sociology}

\author{
V. A. Lukov \\ Moscow University for the Humanities, \\ D. A. Tikhomirov \\ Plekhanov Russian University of Economics
}

The article presents the main features of the Chicago School of Sociology that was formed in the 1920-1930s. Among its major scholars were R. Park and E. Burgess. The authors discuss the role of this school in the development of the qualitative strategy in sociology. The specific characteristics of the Chicago School and other schools of thought are discussed through the lens of the ideas of the thesaurus approach.

Keywords: sociology; Chicago School of Sociology; qualitative strategy; empirical sociology; Robert Park; Ernst Burgess; thesaurus approach

\section{ВВЕДЕНИЕ}

Историю эмпирической социологии можно начинать с социальных опросов, проводившихся еще в XVIII веке в некоторых странах Европы, с социальной физики А. Кетле, откуда идет линия на становление социальной статистики и начинается институциализация этого направления путем созда- 
ния во многих европейских странах государственных систем сбора и анализа статистических данных о населении (Луков, 2001: 8-13). Можно заглянуть и в предысторию: в проведение еще в Древнем Китае, а потом в библейских странах, в античных Греции и Риме переписей населения, в переписи, обозначенной «День Страшного суда», времен Вильгельма Завоевателя в Англии раннего Средневековья и т. д. Но все же искать здесь начала стратегических линий количественной и качественной социологии было бы сильным преувеличением и вряд ли уместно, поскольку в подлинном смысле эмпирические исследования в социологии надо связывать с американским этапом развития этой науки в XX веке: именно здесь и в это время они стали регулярно применяться в интересах бизнеса и развития государственного и муниципального управления, стали рутинной и обязательной частью социологического исследования в любой сфере - от организации производства до преодоления девиаций различного рода.

В этом духе и следует посмотреть на Чикагскую социологическую школу, привлекавшую внимание и вызывавшую подражания в 1915-1934 гг., когда она получила развитие и выявила свои лучшие качества, которые потом, по мере укрепления количественной стратегии, на многие годы ушли в тень (хоть школа по-прежнему и признавалась как классическая), но потом снова заняли свое место в социологии, после того как количественная стратегия показала свои незаметные ранее слабости, что относилось уже к концу 1960-х гг.

Становление и развитие Чикагской школы позволяет увидеть важные черты любых научных школ периода их расцвета, а именно: 1) требуется особое стечение обстоятельств, которое делает становление научной школы непредсказуемым событием, хотя можно заранее предположить, что определенная общественная потребность непременно породит какой-то феномен, ее реализующую, причем это, вероятно, будет организация, которая сможет придать этому феномену пространственно-временные формы; 2) для школы обязательным станет ингрупповой фаворитизм - причем, не всегда в версии М. Шерифа, показавшего зависимость этого социально-психологического феномена от конкуренции за ограниченные ресурсы (Sherif et al., 1961: 155184): возможно, формирование культурных групп (Efferson, Lalive, Fehr, 2008) имеет здесь преимущественное значение; 3) школа непременно будет формироваться вокруг лидера или лидеров, который (которые) обладает неким магнетизмом личности, а не только магнетизмом идеи.

В этих трех аспектах и рассмотрим Чикагскую социологическую школу - не столько как важный эпизод из истории социологии, сколько как реализацию идеи развития науки через формирование научных сообществ, в том числе и в форме научных школ. 


\section{ВОЗНИКНОВЕНИЕ \\ ЧИКАГСКОЙ ШКОЛЬ}

Многие обстоятельства возникновения Чикагской социологической школы были счастливой случайностью. Довольно велика была доля случайности в том, что в частный университет, незадолго до того открытый (в 1891 г.), пришли работать такие авторитетные исследователи, как основоположник прагматизма и теории новой школы Джон Дьюи (1859-1952) и крупнейшие социологи старшего поколения Албион Вудбери Смолл, Джордж Эдгар Винсент, Чарлз Ричмонд Хендерсон и Уильям Айзек Томас - так называемая «большая четверка» (Козер, 2013: 312-313). Случайным было и то, что будущий лидер Чикагской социологической школы Роберт Эзра Парк слушал курс логики у Дьюи еще в бытность последнего профессором Мичиганского университета (где Парк учился на филологическом факультете), а много лет спустя случайно встретился с ним и увлекся его идеей издания газеты нового типа - с просветительскими задачами (Парк к этому времени имел 5-летний стаж репортерской работы). Биографы Парка считают, что этот незавершенный проект направил исследовательский интерес Парка в сторону осмысления широкого круга социальных процессов (История ..., 1997: 118).

Это потребовало от Парка новых профессиональных знаний, и он начал снова учиться - сначала в Гарвардском университете (где изучал философию у У. Джемса, Дж. Ройса, Дж. Сантаяны, а психологию у Г. Мюнстенберга - ученика В. Вундта), а затем в Германии, где прошел курс социологии у Г. Зиммеля, оказавшего на него большое влияние, и написал диссертацию «Толпа и публика: методологическое и социологическое исследование» под руководством В. Виндельбанда (лидера Баденской школы неокантианства). Вернувшись из Европы в Гарвард в 1903 г., Парк, по его словам, «был уже не журналистом, а исследователем» (цит. по: Там же: 314), в течение года работал ассистентом по философии. Однако в тот момент он решил отказаться от планов построения академической карьеры, объяснив это так: «После шести лет занятий философией я немного устал от академической атмосферы. Мне хотелось возобновить связь с миром людей и вещей» (цит. по: Там же: 312). Покинув университет, он познакомился с Б. Вашингтоном (ректор института в Таскеги и общественный деятель, инициировавший программу обучения американских негров сельскохозяйственным наукам и ремеслам) и работал его секретарем на протяжении семи лет, сопровождая его в поездках по южным штатам Америки и другим странам. В 1914 г. У. Томас привлек Парка к преподаванию в Чикагском университете, и они вместе четыре года формировали основы своей социологической школы (там же: 302 ).

После ухода Томаса из университета его место в паре лидеров школы занял молодой исследователь Эрнст Бёрджесс, в прошлом студент этого университета, ученик Парка и Томаса. В плане соотношения количественной и качественной стратегий важно заметить, что он вполне был увлечен фактически выполненной в качественной стратегии многотомной книги У. Томаса и 
Ф. Знанецкого «Польский крестьянин в Европе и Америке» (Thomas, Znaniecki, 1918-1920), но он проявил себя именно в стратегии количественной и был одним из первых социологов, применивших в исследовательских целях компьютер (Shils, 1991). Работа 1928 г. по созданию шкалы успешности условно-досрочно осужденных показывает, что количественная стратегия Бёрджессу была близка: он, в частности, создал метод регрессии с единичным взвешиванием, использовавшийся в этой стратегии как оправдавший себя (Burgess, 1928).

Однако в этой серии случайностей проявился своего рода «интерес эпохи» (М. Вебер). Прежде всего, социология к началу XX века приобрела статус науки, в ней возникали ростки практически полезного знания. Далее социология в Чикагском университете развивалась в условиях, когда факультет участвовал в выполнении социального заказа - разработке городских социальных реформ. Социальный заказ для социологов в то время еще редкость. Городские власти Чикаго встретились с огромными трудностями в период, когда в Америку хлынули десятки тысяч эмигрантов из стран Европы, город стал местом оседания эмигрантских групп, которые в 1900 г. составляли половину его населения. Проблемы адекватного социального контроля и согласия в городе, ставшем символом преступности, администрация Чикаго попыталась решать, опираясь на свой университет, на его социологический факультет, где социальный реформизм был идейным знаменем всего коллектива. И университет оказался на уровне ситуации. Именно здесь укрепилось такое понимание задач социологии, которое на первое место ставило добывание конкретного знания о социальных фактах, полезное для практики решения общественных проблем.

Наконец, огромное значение имело то, что Парк включил в исследовательскую работу студентов и аспирантов. В духе сотрудничества профессоров и студентов Парком и Бёрджессом был создан и учебник «Введение в науку социологии» (1921, второе издание 1924), более тысячи страниц которого составляли 196 отрывков из трудов Г. Зиммеля, Ч. Х. Кули, У. Томаса, Г. Спенсера, Ч. Дарвина, Э. Дюркгейма, Г. Тарда, Г. Лебона, Р. Парка и др. Влияние Зиммеля на Парка особо отразилось в этой книге: в библиографическом указателе здесь максимальное число ссылок на его работы (более 40), избранных отрывков из произведений Зиммеля - больше всего. В предисловиях к 14 разделам книги излагались принципиальные положения социологической теории и методологии и техники эмпирического исследования.

«Введение в науку социологии» стало самым серьезным учебникомхрестоматией в ранний период американской социологии. Цель этой книги, окрещенной в университете «Зеленой Библией», - выработать у студента активное отношение к предмету, поскольку социология — это «общее предприятие» преподавателей и студентов.

Важнейшие идеи учебника, выражающие подходы Чикагской школы к социологии, таковы (см.: Park, Burgess, 1921): 
1. Социология представляет собой науку о коллективном поведении, это «точка зрения и метод исследования процесса, посредством которого индивиды включаются в определенного рода непрерывное корпоративное существование, называемое общество» (цит. по: История ... , 1997: 119).

2. Социология имеет своим итогом социальное реформирование действительности. Отсюда центральными проблемами социологической теории являются «социальные изменения», «социальный контроль», «коллективное (корпоративное) действие».

3. Объяснение общества с позиций теории социального прогресса следует отвергнуть, поскольку оно противоречит тому, что объекты социологического исследования (город, например) имеют естественное происхождение, как и процессы их изменения; естественностью обладают как согласие, так и конфликт, представляющие собой две стороны эволюционного процесса.

4. На макросоциальном уровне эволюционный процесс характеризуется объективацией социальных норм, которые лежат в основе социального контроля; на микросоциальном уровне этот процесс реализуется через личность в ее взаимодействии с другими личностями. Всеобщность (холлизм) первого уровня соединяется с индивидуализмом (атомизмом) второго.

5. Социологические исследования (с тем чтобы соответствовать социально-реформистской сверхзадаче социологии) должны иметь локальный, региональный характер.

Совместное участие профессоров и студентов в городских реформах, социальный заказ на исследование нетривиальных тем (например, поведение уличных компаний), необходимость для решения практических исследовательских задач продвинуть вперед теоретические разработки - эти обстоятельства и определили то, что сформировалась Чикагская социологическая школа.

В основе парадигмы Чикагской школы, как считает один из ее исследователей Дж. Фот (Faught, 1980), лежат следующие шесть исходных предпосылок:

1) Индивид тесно взаимосвязан с группой. Поэтому исследователю следует выявить социальные механизмы, лежащие вне индивида, чтобы объяснить социальный порядок или беспорядок. Здесь возникает центральная для представителей данного направления проблема социального контроля.

2) Сравнительные наблюдения за социальными группами или обществами должны быть обобщенными. Коллективное поведение не следует рассматривать как качественно отличное от рутинного взаимодействия более стабильных групп.

3) Общество представляет собой определенную целостность, не исключающую конфликта между различными социальными группами.

4) Переход от коллективного поведения к институциональному является естественным процессом. Повторяющиеся последствия этого процесса можно выявить при помощи сравнительного анализа. 
5) В ходе социального взаимодействия сознательная деятельность становится все более важной.

6) Социальное взаимодействие имеет рефлексивный характер, сознание и учет членами групп интересов друг друга позволяет создать моральную общность.

\section{РОБЕРТ ПАРК \\ КАК ЛИДЕР ЧИКАГСКОЙ ШКОЛЫ}

К моменту прихода в Чикагский университет Р. Парк, которому было 50 лет, имел богатый жизненный, профессиональный и образовательный опыт, что сформировало широкий круг его научных интересов, отразившийся в исследовательской программе изучения проблем человеческой природы и социального порядка в условиях городской среды Чикаго, которую он осуществлял вместе со своими коллегами и учениками на протяжении двадцати лет работы на факультете. Разнообразие талантов Парка было поразительным. Придя в Чикагский университет, он начал читать курсы «Негры в Америке», «Пресса», «Толпа и публика», «Опрос». Новые теоретические, методологические, методические идеи неудержимо рождались в его голове, и он их не берег для себя, свободно отдавая на разработку ученикам. Таким путем возникли индексация районирования города, развитая Бёрджессом и Маккензи, понятие «социальная дистанция», используя которое Э. Богардус создал свою шкалу (шкала Богардуса).

Основным объектом изучения стал город, который рассматривался в качестве своего рода социальной лаборатории (по аналогии с клинической лабораторией в психологии). В статье «Город: предложения по исследованию человеческого поведения в городской среде» (1915) Парк это объясняет так: «Ввиду тех возможностей, которые предлагает большой город, особенно исключительным и анормальным типам человека, он обычно развертывает во всей красе и буквально выставляет напоказ все те качества и черты, которые обычно скрыты и подавлены в меньших по размеру сообществах. Короче говоря, город показывает в преувеличенном виде добро и зло в человеческой природе. Наверное, это более чем что-либо оправдывает взгляд, делающий город лабораторией или клиникой, в которой удобнее и плодотворнее всего изучать человеческую природу и социальные процессы» (Парк, 2011a: 56).

В понимании общества Парком проявились две особенности. Первая состояла в выделении у общества свойств, позволяющих о нем говорить не только как о социальном, но и биологическом феномене: общество имеет как социальный (т. е. культурный), так и биотический уровень, который и составляет основу социального развития. Вторая - определение общества через контроль, функция которого - организовывать, интегрировать и направлять усилия составляющих его индивидов (Парк, 1999).

Социальный контроль коллективного поведения стал ведущей темой социологии Парка. В его представлении коллективное поведение не всегда 
имеет атрибуты социального и может быть стихийным, основанным на психических реакциях. Обращение коллективного в социальное поведение происходит, когда под влиянием культурных факторов, имеющих характер социального контроля (традиции, обычаи, нравственные и правовые нормы и т. д.), действия людей становятся согласованными, приобретают корпоративность. Социальный контроль, таким образом, через общие для всех символы, знаки, значения превращает коллективное поведение во взаимодействие.

В рассмотрении коллективного поведения Парк придавал особое значение двум методологическим принципам:

1) простой фиксации коллективного поведения недостаточно, надо его понять, что достигается «сочувственным отождествлением» исследователя с исследуемым объектом;

2) социальное явление следует изучать в его развитии, сосредоточивая исследовательский интерес на процессе, а не результате.

Эти общие положения стали исходными в разработке Парком концепции, которая в 1930-е гг. была названа им «человеческая экология» (одноименная статья была опубликована в 1936 г.). В общем плане человеческая экология представляет собой исследование отношений между людьми, определяемых помимо прочего средой их обитания. «Человеческая экология, поясняет Парк, - стремится вынести на передний план не столько географию, сколько пространство. В обществе мы живем не только вместе, но в то же время по отдельности, и человеческие отношения всегда можно рассмотреть с большей или меньшей точностью в терминах дистанции. Поскольку социальную структуру можно определить через позиции, то социальные изменения могут быть описаны в терминах движения...» (Парк, 2011b: 67). Суть концепции такова.

1. Общество обладает, кроме других свойств, «системой жизненных функциональных связей между людьми» - симбиотической или экологической системой. Парк подчеркивал, что «проявления живого, изменяющегося, но устойчивого порядка среди конкурирующих организмов - организмов, воплощающих в себе “конфликтующие, но взаимосвязанные интересы" являются, по всей видимости, основой для понятия социального порядка, относящегося к отдельным видам, и к обществу, покоящемуся, скорее, на биотическом, нежели культурном основании...» (Парк, 1999: 386).

2. В обществе биотические и культурные структуры взаимосвязаны и выстроены в определенном порядке. Культурная надструктура, хотя и основывается на биотической подструктуре, довлеет как направляющая и контролирующая инстанция над биотической субструктурой. На биотическом уровне порядок создается и поддерживается главным образом конкуренцией, а на культурном - коммуникацией. Именно коммуникация, формируя сеть обычаев и взаимных ожиданий, делает возможными консенсус и понимание между индивидами: «...она неизменно видоизменяет и ограничивает конку- 
ренцию, и культурный порядок накладывает ограничения на порядок симбиотический» (Парк, 2011с: 146).

3. Конкуренция создает особый тип организации - сообщество, а коммуникация - общество. Для анализа человеческого общества с точки зрения человеческой экологии Парк использовал понятие «сообщество», определяемое им как «собрание индивидов, живущих вместе, подобно растениям и животным, в пределах общего хабитата». Общество в понимании Парка является «не просто скоплением относительно фиксированных и оседлых единиц, а ассоциацией индивидов, участвующих в коллективном акте» (Парк, 2011d: 116). Именно способность к согласованному действию, определяемая коммуникацией, отличает общество от сообщества. Парк рассматривал сообщество как среду обитания (habitat), создающую экономическую организацию и необходимые условия, в которых общества укоренены и на которых, как на физическом базисе, они могут установиться (Парк, 2011е: 84). Такая дифференциация имела и практический смысл. Парк считал, что социологические исследования уместно начинать с сообщества как объекта, характеристики которого лучше поддаются статистической трактовке: его можно «показать, определить его территориальные границы и нанести его составные элементы, население и институты на карты» (там же). Если в сообществе на передний план выходили симбиоз, пространство, физическая структура, конкуренция и разделение труда, то в обществе - коммуникация, консенсус, обычай, социальный контроль и коллективное действие. Отметим, что это идеальнотипическая конструкция, которую, по словам Л. Вирта, зачастую путали с конкретными реальностями, не видя, что все сообщества являются одновременно обществами, а все человеческие общества содержат в себе по крайней мере некоторые из характеристик сообществ (Вирт, 2005: 42).

4. Общество представляет собой иерархию социальных порядков: экологический, экономический, политический и моральный, в основании которой лежит экологический порядок, а на вершине — моральный. Как пишет Р. Парк, «на каждом из последовательно расположенных уровней — на экологическом, экономическом, политическом и моральном - индивид оказывается полнее инкорпорированным в социальный порядок, более подчиненным ему, нежели на предшествующем уровне» (Парк, 1999: 398). Переход от биотического к культурному уровню сопровождается ослаблением конкуренции и усилением социального контроля, приводя к ограничению свободы человека, который менее всего свободен на моральном уровне.

5. Человек в процессе своего развития и инкорпорирования в общество движется от биотического уровня к культурному (проходя тот же цикл событий, что и общество - Парк, 2011d: 139) через конкуренцию, которая имеет такие формы, как соперничество, конфликт, аккомодация (приспособление) и ассимиляция. Такой же путь проходит и чужак, принимаемый в новое общество (там же). Процесс социализации «находит завершение в ассимиляции, предполагающей более или менее полное включение индивида в существу- 
ющий моральный порядок, а также более или менее полное сдерживание конкуренции. В этих условиях конфликт принимает форму более или менее благородного соперничества» (там же: 138). Посредством этих процессов индивид, достигая социального статуса и играя роль в каком-нибудь обществе, становится персоной (личностью), сознающей права и обязанности и в большей или меньшей мере заботящейся об общем благе группы, к которой она принадлежит (Парк, 2011f: 203). Ядром личности индивида является его представление о себе, которое определяется занимаемым социальным статусом и исполняемой ролью, а также представлением, которое имеют о нем другие люди (Парк, 2011g: 62).

6. Общество находится в состоянии постоянных циклических изменений, переходя от нестабильности к порядку через нарушение равновесия (вследствие ослабления социального контроля и усиления конкуренции) и достижение нового (ограничение конкуренции). Парк отмечал, что «экология человека по сути своей является попыткой исследовать процесс, в котором биотический баланс и социальное равновесие 1) сохраняются, как только они установлены и 2) процесс перехода от одного относительно стабильного порядка к другому, как только биотический баланс и социальное равновесие нарушены» (Парк, 1999: 400).

7. Биотический баланс и социальное равновесие поддерживаются взаимодействием четырех элементов (факторов): населения, артефактов (технологической культуры), обычаев и верований (нематериальной культуры) и природных ресурсов среды обитания (там же). По словам ученика Парка Л. Вирта, «физические факторы, хотя и оказывают немалое влияние на социальную жизнь и психологические феномены, являются в лучшем случае обусловливающими факторами, которые открывают возможности и ставят пределы социальному и психологическому существованию и развитию. Иными словами, они создают сцену для человека, актора» (Вирт, 2005: 47).

8. Пространство и изменение положения индивида в пределах естественного ареала (зоны состязательной кооперации) создают особый тип организации, называемый «социальным» (Парк, 2011b: 74). Социальный организм образуется из индивидов, способных к передвижению (там же: 76). Движение населения, т. е. изменения в местоположении индивидов и их занятии, влияющее на существующие формы социального порядка, представляет основной интерес для экологии человека (Парк, 1999).

Идеи, составляющие концепцию социальной экологии, были с успехом применены Парком и его учениками при разработке ряда конкретных социологических проблем.

Изучение данных по Чикаго позволило Парку применить свою трактовку экологического порядка к изучению влияния естественного района проживания на коллективное поведение людей. В книге Парка, Бёрджесса и Маккензи «Город» (1925) трактовка городского развития прямо увязана с пространственными характеристиками: рост населения и интенсивность ми- 
грации ведут к тому, что на одной территории оказывается все больше людей, конкуренция между которыми усиливается. Это способствует разделению труда и формированию социальных институтов, увеличивающих коллективные возможности тех или иных групп (Park, Burgess, McKenzie, 1925).

Некоторые идеи Парка не получили развития или были заметно искажены последователями. Не нашла приложения в исследовательских программах идея Парка о передвижении как основе социальной организации. Впервые введенное Парком понятие маргинальной личности затем существенно трансформировалось и приобрело скорее отрицательный оттенок, чего совсем нет у Парка.

\section{ЭРНСТ БЁРДЖЕСС}

Выпускник Чикагского университета Э. Бёрджесс одним из первых социологов Америки получил степень доктора наук не в Германии, а у себя на родине. Его научный стиль сложился под влиянием научного сообщества Чикагской социологической школы (особенно У. Томаса) и сочетал в себе высокий теоретический уровень с мастерством эмпирических исследований. Вернувшись в родной университет преподавателем (1916), Бёрджесс начал читать целую серию курсов, отражавших как его научные интересы, так и приоритеты социологического факультета (социальная патология, криминология, социология семьи, теория личности). После ухода из университета Томаса в 1918 г. Бёрджесс, читавший также и вводный курс социологии, оказался в ситуации, когда подготовка учебника по социологии, задуманного Томасом, частью легла и на него. В паре Парк-Бёрджесс он вначале выступил соавтором учебника («Введение в науку социологии»), а затем взял на себя методическое обеспечение полевых исследований и их организацию, в чем достиг высоких результатов.

В учебнике по методам социологического исследования (на основе совместного с Парком курса) Бёрджесс дал описание основных методов получения эмпирических данных в полевых исследованиях. Он выделил (1) метод исследования случая (case-study method), (2) исторический метод и (3) статистические методы. Специально была описана методика и техника монографического обследования, основанная на проведении наблюдения, интервью, анализе личных документов и социальном картографировании.

Метод социального картографирования использовался в начале исследования для более точного определения частоты и распределения изучаемых феноменов. Суть его заключалась в том, что на карту наносились всевозможные сведения, касающиеся изучаемого объекта, полученные при анализе данных статистики и других источников. Карты помогали определить локальное место высокой концентрации изучаемого объекта, в котором и проводилось эмпирическое исследование.

Социальное картографирование - как способ объективного, без тенденциозности автора представления реальных социальных различий в их 
территориальном аспекте - стало основным методом в рамках исследования «Город как социальная лаборатория», проведенного на материале Чикаго. Бёрджесс, привлекая студентов университета, создал «карту социальных исследований города Чикаго» (1923-1924). В этом, как и в других исследованиях, Бёрджесс исходил из концепции социальной экологии, развивая и подтверждая новыми аргументами ее базовые положения.

Наибольший вклад в развитие социальной экологии внесла работа Бёрджесса 1925 г. «Рост города: введение в исследовательский проект» (Бёрджесс, 2015). В ней он рассматривает процессы, заключенные в росте города: экспансии, городского метаболизма и мобильности. Анализ социальных карт Чикаго, выполненных по различным показателям социальной дифференциации, позволил ему выдвинуть оригинальную концепцию «концентрических зон» города. Ее основные положения таковы:

1. Город представляет собой социальный организм, пространственно расположенный в виде определенных концентрических зон - крупных территориальных и социальных образований.

2. Город развивается, что отражается на его концентрических зонах. Рост города идет неравномерно и сопровождается подвижностью границ как территориальных, так и социальных. Развитие города происходит волнами от центра к окраинам. Каждая внутренняя зона стремится к последовательному расширению (Бёрджесс этот процесс называл сукцессией) своей территории путем проникновения в следующую внешнюю зону.

3. При развитии города происходят дополняющие друг друга процессы концентрации и децентрализации. Во всех городах существует естественная тенденция к схождению транспортных коммуникаций в центральном деловом районе, который становится сосредоточием экономической, культурной и политической жизни, ежедневно аккумулирующей значительные массы населения из различных районов города. Центральный деловой район господствует над подчиненными деловыми районами, формирующимися в системе локальных сообществ, так же, как и метрополис — над разрастающимися городами-спутниками.

4. Особое место среди концентрических зон занимает зона перехода (транзита), непосредственно примыкающая к центру города. Ее специфика в возникающей зависимости от роста центра как зоны активной экономической деятельности. Этот рост приводит к увеличению цен на землю, который расходится из делового центра круговыми волнами во все части города. Как отмечает Р. Парк, «если цены на землю в центре быстро растут, это увеличивает радиус прилегающей территории, которая придерживается для спекулятивных целей. Недвижимость, удерживаемая с целью спекуляции, обычно доводится до обветшания. Она легко приобретает характер трущобы, т. е. ареала случайного и непостоянного населения, грязи и запущенности... Эти запущенные и иногда полностью заброшенные районы становятся местами 
первого поселения иммигрантов. Здесь располагаются наши гетто и иногда наши богемные кварталы...» (Парк, 2011b: 69).

5. Рост города сопровождается распределением населения по разным местам проживания и родам занятий, приводя к дифференциации города на неоднородные ареалы и образованию локальных сообществ, что проявляется в концентрических зонах.

6. Развитие города приводит к изменению не только его пространственных границ, но и социальной организации, и личностных типов. Рост города нарушает равновесие социального порядка, когда дезорганизация берет верх над организацией.

7. Основной причиной нарушения социального равновесия города является пространственная и социальная мобильность населения.

Мобильность в чикагской традиции понималась как движение, изменение положения человека в пределах сообщества, отражающееся на его социальных контактах. Бёрджесс связал мобильность со стимуляцией, вызывающей реагирование человека «на те объекты его внешнего окружения, которые дают выражение его желаниям», определив ее (мобильность) как «изменение движений в ответ на новый стимул или ситуацию» (Бёрджесс, 2015: 30). Мобильность жизни в городе, где возрастает число и интенсивность стимуляций, неизбежно сбивает людей с пути и ведет к их деморализации. Влияние мобильности на человека в условиях городской жизни Бёрджесс и его коллеги выявили в ходе эмпирических исследований. Соответственно, мобильность становится лучшим индикатором состояния метаболизма города, выступая своего рода «пульсом сообщества»: «Подобно пульсу человеческого тела, этот процесс является отражением и индикатором всех происходящих в сообществе изменений, и его можно разложить на элементы, поддающиеся количественному выражению. Элементы, входящие в состав мобильности, можно подразделить на две основные категории: 1) состояние изменчивости человека-персоны и 2) число и тип контактов или стимуляций в его внешней среде» (там же: 31 ).

В упомянутой выше коллективной работе «Город» (1925) Бёрджесс выделил на материале Чикаго четыре концентрические зоны, а в их рамках 75 «естественных зон» и более 300 «локальных сообществ», ставших затем объектом исследования методами наблюдения, интервью, анализа документов и т. д. - т. е преимущественно выполненных в качественной стратегии.

Это вовсе не значит, что он не владел количественной стратегией или преуменьшал ее роль. Так, разработки в области социологии города привели Бёрджесса к исследованиям по социологии семьи, в которых он исходил из интеракционистской методологии (рассматривал семью как ситуацию межличностного общения). Семья - «единство взаимодействующих личностей», и здесь исследователь видит сосредоточие основных общественных проблем. По состоянию семьи, по Бёрджессу, возможен диагноз состояния общества (История ..., 1997: 137). 
Одним их первых Бёрджесс стал придавать центральное значение в рамках крупных исследовательских программ формулированию гипотез с целью их последующей проверки. В работах по социологии семьи, которые он вел в 1926 г. в СССР на материале семей молокан (для чего изучил русский язык) он применил факторный анализ - в то время мало известное социологам средство обобщения первичной социологической информации.

\section{ЗАКЛЮЧЕНИЕ}

«Введение в науку социологии» Р. Парка и Э. Бёрджесса и «Польский крестьянин в Европе и Америке» У. Томаса и Ф. Знанецкого определили контуры Чикагской социологической школы. В ней сочетались серьезные шаги к теоретическому осмыслению социальных реальностей США с огромной работой по конкретному описанию самых разных и нередко труднодоступных для исследователя сообществ, ситуаций, систем взаимоотношений. Среди тем, разрабатывавшихся представителями школы, были такие, как положение негров в Чикаго (Ч. Джонсон, Э. Ф. Фрэзер), гетто (Л. Вирт), платные танцзалы (П. Г. Кресси), внутренняя жизнь гостиниц (Н. Хэйнер), преступность и молодежная делинквентность (К. Шоу), шайки (Ф. М. Трэшер), организованная преступность (Дж. Ландеско), занятия и профессии (Ф. Р. Донован, Э. Ч. Хьюз), забастовка (Э. Т. Хиллер), газеты (Р. Э. Парк, Х. М. Хьюз), общины хлыстов (П. Янг), самоубийство (Р. Кэван), проституция (У. Реклесс) и др. Особенность исследуемого материала предопределила широкое экспериментирование в области методики исследования, способов сбора первичной информации. Отсюда широкое использование включенного наблюдения, неструктурированного интервью, анализа личных документов, которые впервые применялись на систематической основе.

Крупнейшим достижением в методике исследования стало соединение воедино данных различным образом полученных описаний локальных сообществ. На этой базе сформировались основы метода исследования случая (case-study method), базирующегося на неструктурированном интервью и позволяющего представить структурно-функциональные характеристики изучаемого сообщества через раскрытие мотивации и структуры поведения индивидов.

То, что применение метода исследования случая в социологических целях напоминало журналистские расследования, было сознательной установкой школы. Парк подчеркивал, что социолог — это очень аккуратный, ответственный и хорошо подготовленный в различных областях науки репортер.

Переход к экспериментальной проверке гипотез означал новаторскую линию школы и в области применения статистических методов, однако к 1934 г. - году ухода Парка из Чикагского университета — на научном горизонте появились новые школы. Колумбийский и Гарвардский университеты принимают на себя роль лидеров в социологии, и их представители с этого 
времени определяют основные направления развития социологической теории и практики.

Но только ли в уходе Парка дело? Ведь и он, и Бёрджесс, и Томас, и Знанецкий, и другие ведущие ученые этой школы продолжали свою научную деятельность, не отказываясь от своих более ранних идей, но даже, напротив, всячески их развивая и обосновывая. Представляется убедительным видеть причины потери Чикагской школой своего первенства в области ее теоретических установок, которые уже не удовлетворяли научное сообщество 1930-х ГГ.

Прежде всего речь идет о четкой направленности теории на локальную проблематику. Как практическая позиция локализм дал великолепные результаты. То, что «чикагцы» занимались проблемами своего города, предопределило их успех и двинуло вперед практически-прикладное использование социологии. Но уже в годы Великой депрессии (1929-1933) в американском обществе все отчетливее проглядывали черты общенациональных, а не региональных, локальных проблем. Исследования локального характера мало могли дать для понимания источников этих проблем и путей их системного разрешения.

Другим важным обстоятельством надо считать нововведения в области техники сбора и обработки первичной социологической информации. Формируется техника анкетного опроса, возникает теория выборки. Анкетные опросы становятся и элементом моды, им доверяют больше, чем интерпретациям писем или записей свободных интервью, как преимущественно делалось у «чикагцев». Новое понимание эмпирического исследования в этот период свойственно не только американской социологии. Характерной демонстрацией возникшего в мировом научном сообществе стремления к эмпирическому доказательству выдвигаемых гипотез стали, например, положения «социальной философии» М. Хоркхаймера, согласно которым любые общественные тенденции в «разумном» обществе предсказуемы и могут быть представлены в виде точных формул (Bock, 1980).

Следовательно, преимущества и недостатки количественной или качественной стратегии в эмпирической социологии не зависят только от их действительных свойств, которые требуют трактовки и признания в научном сообществе. Вот где и сказываются особенности научных школ, а именно: a) особое стечение обстоятельств, включая как наблюдаемое Происходящее (в трактовке И. М. Ильинского), так и ситуацию в данной науке (группе наук); б) ингрупповой фаворитизм как способ отделить «своих» от «чужих» с выделением достоинств (реальных или мнимых) «своих», что выражает тезаурусный принцип построения научных школ и понятен именно в условиях применения тезаурусного подхода (тезаурусной социологии); 3) наличие лидера (или лидеров), которому есть что предложить научному сообществу, а в первую очередь своим сподвижникам и ученикам, захваченным и масштабом идей, и магнетизмом личности лидера. 


\section{СПИСОК ЛИТЕРАТУРЫ}

Бёрджесс, Э. У. (2015) Рост города: введение в исследовательский проект // Чикагская социология : сб. переводов / РАН. ИНИОН. Центр социальных научно-информационных исследований. Отдел социологии и социальной психологии ; сост. и пер. с англ. В. Г. Николаев ; отв. ред. Д. В. Ефременко. М. : ИНИОНРАН. 430 с. С. 20-34.

Вирт, Л. (2005) Человеческая экология // Вирт Л. Избранные работы по социологии : сб. переводов / РАН. ИНИОН. Центр социальных научноинформационных исследований. Отдел социологии и социальной психологии ; пер. с англ. В. Г. Николаев ; отв. ред. Л. В. Гирко. М. : ИНИОН РАН. 244 с. C. $39-50$.

История теоретической социологии (1997) : в 4 т. / отв. ред. и сост. Ю. Н. Давыдов. М. : Канон. Т. 3. 448 с.

Козер, Л. А. (2013) Мастера социологической мысли. Идеи в историческом и социальном контексте / под ред. И. Б. Орловой ; пер. с англ. Т. И. Шумилиной. СПб. : Нестор-История. 464 с.

Луков, В. А. (2001) История социологии в конспективном изложении: учеб. пособие. М. : Социум. Ч. І. 160 с.

Парк, Р. Э. (1999) Экология человека // Теория общества: фундаментальные проблемы : сборник / под ред. А. Ф. Филиппова. М. : КАНОН-прессЦ ; Кучково поле. 416 с. С. 384-400.

Парк, Р. Э. (2011а) Город: предложения по исследованию человеческого поведения в городской среде // Парк Р. Э. Избранные очерки : сб. переводов / РАН. ИНИОН. Центр социал. научн.-информ. исследований. Отд. социологии и социал. психологии ; сост. и пер. В. Г. Николаев ; отв. ред. Д. В. Ефременко. М. : ИНИОН РАН. 320 с. С. 19-56.

Парк, Р. Э. (2011b) Городское сообщество как пространственная конфигурация и моральный порядок // Парк Р. Э. Избранные очерки : сб. переводов / РАН. ИНИОН. Центр социал. научн.-информ. исследований. Отд. социологии и социал. психологии ; сост. и пер. В. Г. Николаев ; отв. ред. Д. В. Ефременко. М. : ИНИОН РАН. 320 с. С. 66-79.

Парк, Р. Э. (2011с) Размышления о коммуникации и культуре // Парк Р. Э. Избранные очерки : сб. переводов / РАН. ИНИОН. Центр социал. научн.информ. исследований. Отд. социологии и социал. психологии ; сост. и пер. В. Г. Николаев ; отв. ред. Д. В. Ефременко. М. : ИНИОН РАН. 320 с. С. 140 157.

Парк, Р. Э. (2011d) Симбиоз и социализация: схема соотнесения для изучения общества // Парк Р. Э. Избранные очерки : сб. переводов / РАН. ИНИОН. Центр социал. научн.-информ. исследований. Отд. социологии и социал. психологии ; сост. и пер. В. Г. Николаев ; отв. ред. Д. В. Ефременко. М. : ИНИОН РАН. 320 с. С. 115-139.

Парк, Р. Э. (2011е) Социология, сообщество и общество // Парк Р. Э. Избранные очерки : сб. переводов / РАН. ИНИОН. Центр социал. научн.- 
информ. исследований. Отд. социологии и социал. психологии ; сост. и пер. В. Г. Николаев ; отв. ред. Д. В. Ефременко. М. : ИНИОН РАН. 320 с. С. 80114.

Парк, Р. Э. (2011f) Личность и культурный конфликт // Парк Р. Э. Избранные очерки : сб. переводов / РАН. ИНИОН. Центр социал. научн.информ. исследований. Отд. социологии и социал. психологии ; сост. и пер. В. Г. Николаев ; отв. ред. Д. В. Ефременко. М. : ИНИОН РАН. 320 с. С. 201216.

Парк, Р. Э. (2011g) Человеческая природа и коллективное поведение // Парк Р. Э. Избранные очерки : сб. переводов / РАН. ИНИОН. Центр социал. научн.-информ. исследований. Отд. социологии и социал. психологии ; сост. и пер. В. Г. Николаев ; отв. ред. Д. В. Ефременко. М. : ИНИОН РАН. 320 с. C. 57-65.

Bock, M. (1980) Soziologie als Grundlage des Wirklichkeitsverständnisses: Zur Entstehung des modernen Weltbildes. Stuttgart : Klett-Kotta. $217 \mathrm{~S}$.

Burgess, E. W. (1928) Factors determining success or failure on parole // The workings of the indeterminate-sentence law and the parole system in Illinois : A report to the Honorable Hinton G. Clabaugh, chairman, Parole board of Illinois / ed. by A. A. Bruce. Chicago : S.n. xiv, 277 p. P. 205-249.

Efferson, Ch., Lalive, R., Fehr, E. (2008) The coevolution of cultural groups and ingroup favoritism // Science. Vol. 321. No. 5897. P. 1844-1849. DOI: 10.1126/science. 1155805

Faught, J. (1980) Presuppositions of the Chicago school in the work of Everett C. Hughes // The American Sociologist. Vol. 15. No. 2. P. 72-82.

Park, R. E., Burgess, E. W. (1921) Introduction to the science of sociology. Chicago : The University of Chicago Press. xxi, 1040 p.

Park, R. E., Burgess, E. W., McKenzie, R. D. (1925) The city. Chicago : The University of Chicago Press. xi, 239 p.

Sherif, M. et al. (1961) Intergroup conflict and cooperation: The Robbers Cave experiment / M. Sherif, O. J. Harvey, B. J. White, W. R. Hood, C. W. Sherif. Norman, OK : The University of Oklahoma Press. xii, 212 p.

Shils, E. (1991) Ernest W. Burgess // Remembering the University of Chicago. Teachers, scientists, and scholars / ed. by E. Shils. Chicago : The University of Chicago Press. xxi, 593 p. P. 3-14.

Thomas, W. I., Znaniecki, F. (1918-1920) The Polish peasant in Europe and America : in 5 vols. Boston : Richard G. Badger.

Дата поступления: 20.01.2019 г.

\section{REFERENCES}

Burgess E. W. (2015) Rost goroda: vvedenie v issledovatel'skii proekt [The growth of the city: An introduction to a research project]. In: Chikagskaia sotsiologiia [Chicago sociology] : A collection of translations / collect. and transl. 
from English by V. G. Nikolaev ; ed. by D. V. Efremenko. Moscow : Institute of Scientific Information on Social Sciences of the Russian Academy of Sciences. 430 p. Pp. 20-34. (In Russ.).

Wirth, L. (2005) Chelovecheskaia ekologiia [Human ecology]. In: Wirth, L. Izbrannye raboty po sotsiologii [Collected works in sociology] : A collection of translations / transl. from English by V. G. Nikolaev; ed. by L. V. Girko. Moscow : Institute of Scientific Information on Social Sciences of the Russian Academy of Sciences. 244 p. Pp. 39-50. (In Russ.).

Istoriia teoreticheskoi sotsiologii [History of theoretical sociology] (1997) : in 4 vols. / ed. and collect. by Yu. N. Davydov. Moscow : Kanon Publ. Vol. 3. 448 p. (In Russ.).

Coser, L. A. (2013) Mastera sotsiologicheskoi mysli. Idei v istoricheskom $i$ sotsial'nom kontekste [Masters of sociological thought: Ideas in historical and social context] / ed. by I. B. Orlova ; transl. from English by T. I. Shumilina. St. Petersburg : Nestor-Istoriia Publ. 464 p. (In Russ.).

Lukov, V. A. (2001) Istoriia sotsiologii v konspektivnom izlozhenii [A summary of the history of sociology] : A study guide. Moscow : Sotsium Publ. Pt. I. 160 p. (In Russ.).

Park, R. E. (1999) Ekologiia cheloveka [Human ecology]. In: Teoriia obshchestva: fundamental'nye problemy [Theory of society: fundamental issues] : A collection / ed. by A. F. Filippov. Moscow : KANON-press-Ts Publ. ; Kuchkovo pole Publ. 416 p. Pp. 384-400. (In Russ.).

Park, R. E. (2011a) Gorod: predlozheniia po issledovaniiu chelovecheskogo povedeniia $\mathrm{V}$ gorodskoi srede [The city: Suggestions for investigation of human behavior in the urban environment]. In: Park, R. E. Izbrannye ocherki [Collected papers] : A collection of translations / collect. and transl. by V. G. Nikolaev; ed. by D. V. Efremenko. Moscow : Institute of Scientific Information on Social Sciences of the Russian Academy of Sciences. 320 p. Pp. 19-56. (In Russ.).

Park, R. E. (2011b) Gorodskoe soobshchestvo kak prostranstvennaia konfiguratsiia i moral'nyi poriadok [The urban community as a spatial pattern and a moral order.]. In: Park, R. E. Izbrannye ocherki [Collected papers] : A collection of translations / collect. and transl. by V. G. Nikolaev; ed. by D. V. Efremenko. Moscow : Institute of Scientific Information on Social Sciences of the Russian Academy of Sciences. 320 p. Pp. 66-79. (In Russ.).

Park, R. E. (2011c) Razmyshleniia o kommunikatsii i kul'ture [Reflections on communication and culture]. In: Park, R. E. Izbrannye ocherki [Collected papers] : A collection of translations / collect. and transl. by V. G. Nikolaev ; ed. by D. V. Efremenko. Moscow : Institute of Scientific Information on Social Sciences of the Russian Academy of Sciences. 320 p. Pp. 140-157. (In Russ.).

Park, R. E. (2011d) Simbioz i sotsializatsiia: skhema sootneseniia dlia izucheniia obshchestva [Symbiosis and socialization: A frame of reference for the study of society]. In: Park, R. E. Izbrannye ocherki [Collected papers] : A collection of translations / collect. and transl. by V. G. Nikolaev ; ed. by D. V. Efremen- 
ko. Moscow : Institute of Scientific Information on Social Sciences of the Russian Academy of Sciences. 320 p. Pp. 115-139. (In Russ.).

Park, R. E. (2011e) Sotsiologiia, soobshchestvo i obshchestvo [Sociology, community and society]. In: Park, R. E. Izbrannye ocherki [Collected papers] : A collection of translations / collect. and transl. by V. G. Nikolaev ; ed. by D. V. Efremenko. Moscow : Institute of Scientific Information on Social Sciences of the Russian Academy of Sciences. 320 p. Pp. 80-114. (In Russ.).

Park, R. E. (2011f) Lichnost' i kul'turnyi konflikt [Cultural conflict and the marginal man]. In: Park, R. E. Izbrannye ocherki [Collected papers] : A collection of translations / collect. and transl. by V. G. Nikolaev ; ed. by D. V. Efremenko. Moscow : Institute of Scientific Information on Social Sciences of the Russian Academy of Sciences. 320 p. Pp. 201-216. (In Russ.).

Park, R. E. (2011g) Chelovecheskaia priroda i kollektivnoe povedenie [On social control and collective behavior]. In: Park, R. E. Izbrannye ocherki [Collected papers ] : A collection of translations / collect. and transl. by V. G. Nikolaev ; ed. by D. V. Efremenko. Moscow : Institute of Scientific Information on Social Sciences of the Russian Academy of Sciences. 320 p. Pp. 57-65. (In Russ.).

Bock, M. (1980) Soziologie als Grundlage des Wirklichkeitsverständnisses: Zur Entstehung des modernen Weltbildes. Stuttgart : Klett-Kotta. 217 S. (In Germ.).

Burgess, E. W. (1928) Factors determining success or failure on parole. In: The workings of the indeterminate-sentence law and the parole system in Illinois: A report to the Honorable Hinton G. Clabaugh, chairman, Parole board of Illinois / ed. by A. A. Bruce. Chicago : S.n. xiv, 277 p. Pp. 205-249.

Efferson, Ch., Lalive, R. and Fehr, E. (2008) The coevolution of cultural groups and ingroup favoritism. Science, vol. 321, no. 5897, pp. 1844-1849. DOI: 10.1126/science. 1155805

Faught, J. (1980) Presuppositions of the Chicago school in the work of Everett C. Hughes. The American Sociologist, vol. 15, no. 2, pp. 72-82.

Park, R. E. and Burgess, E. W. (1921) Introduction to the science of sociology. Chicago :The University of Chicago Press. xxi, $1040 \mathrm{p}$.

Park, R. E., Burgess, E. W. and McKenzie, R. D. (1925) The city. Chicago : The University of Chicago Press. xi, $239 \mathrm{p}$.

Sherif, M. et al. (1961) Intergroup conflict and cooperation: The Robbers Cave experiment / M. Sherif, O. J. Harvey, B. J. White, W. R. Hood, C. W. Sherif. Norman, OK : The University of Oklahoma Press. xii, 212 p.

Shils, E. (1991) Ernest W. Burgess. In: Remembering the University of Chicago. Teachers, scientists, and scholars / ed. by E. Shils. Chicago : The University of Chicago Press. xxi, 593 p. Pp. 3-14.

Thomas, W. I. and Znaniecki, F. (1918-1920) The Polish peasant in Europe and America : in 5 vols. Boston : Richard G. Badger. 
Луков Валерий Андреевич - доктор философских наук, профессор, директор Центра социального проектирования и тезаурусных концепций Института фундаментальных и прикладных исследований Московского гуманитарного университета, заслуженный деятель науки Российской Федерации, академик Международной академии наук (IAS, Инсбрук, Австрия). Адрес: 111395, Россия, г. Москва, ул. Юности, 5. Тел.: +7 (499) 374-75-95. Эл. адрес: v-lukov@list.ru

Тихомиров Дмитрий Андреевич — кандидат социологических наук, доцент кафедры политологии и социологии РЭУ им. Г. В. Плеханова. Адрес: 117997, Москва, Стремянный пер., 28, корп. 1. Тел.: +7 (495) 958-23-27. Эл. адрес: dat1983@yandex.ru

Lukov Valery Andreevich, Doctor of Philosophy, Professor, Director, Center for Social Design and Thesaurus Conceptions, Institute of Fundamental and Applied Studies, Moscow University for the Humanities; Honored Scientist of the Russian Federation, Full Member, International Academy of Science (IAS, Innsbruck, Austria). Postal address: 5 Yunosti St., 111395 Moscow, Russian Federation. Tel.: +7 (499) 374-75-95. E-mail: v-lukov@list.ru

Tikhomirov Dmitry Andreevich, Candidate of Sociology, Associate Professor, Department of Political Science and Sociology, Plekhanov Russian University of Economics. Postal address: Bldg. 128, Stremyannyi Lane, 117997 Moscow, Russian Federation. Tel.: +7 (495) 958-23-27. E-mail: dat1983@yandex.ru

\section{Для цุитирования:}

Луков В. А., Тихомиров Д. А. Чикагская социологическая школа: начало качественной стратегии в эмпирической социологии [Электронный ресурс] // Горизонты гуманитарного знания. 2019. № 1. С. 89-107. URL: http:// journals.mosgu.ru/ggz/article/view/953 (дата обращения: дд.мм.гггг). DOI: 10. 17805/ggz.2019.1.5 